\title{
In Case You Missed It: Business News from the Field
}

\section{JOMI Eas Eneres Aserement with themagazine UAE Cement Industry} Dubai, United Arab Emirates: Emirates Global Aluminium (EGA) announced that they have entered into an agreement with the United Arab Emirates (UAE) cement industry to supply carbon dust. A by-

Do you have business or industry news of interest to the minerals, metals, and materials community? Submit your announcement or press release to Kaitlin Calva, JOM Magazine Managing Editor, at kcalva@tms.org for consideration. product that is generated during the process of producing smelting anodes, carbon dust can be used as an alternative fuel. The UAE cement industry plans to use freshly produced carbon dust as a fuel source, reducing the emissions from mining and transporting coal to their facilities.

\section{Arconic to Break Up and Sell Businesses Pittsburgh, Pennsylvania, USA:} Arconic, a lightweight metals engineering and manufacturing company, has announced plans to separate its business portfolio. The company will split into Engineered Products \& Forgings and Global Rolled Products and is considering the sale of businesses that do not best fit into either of these divisions. Additionally, Arconic's board has appointed John C. Plant, current chair of the board, to serve as chair and chief executive officer, and

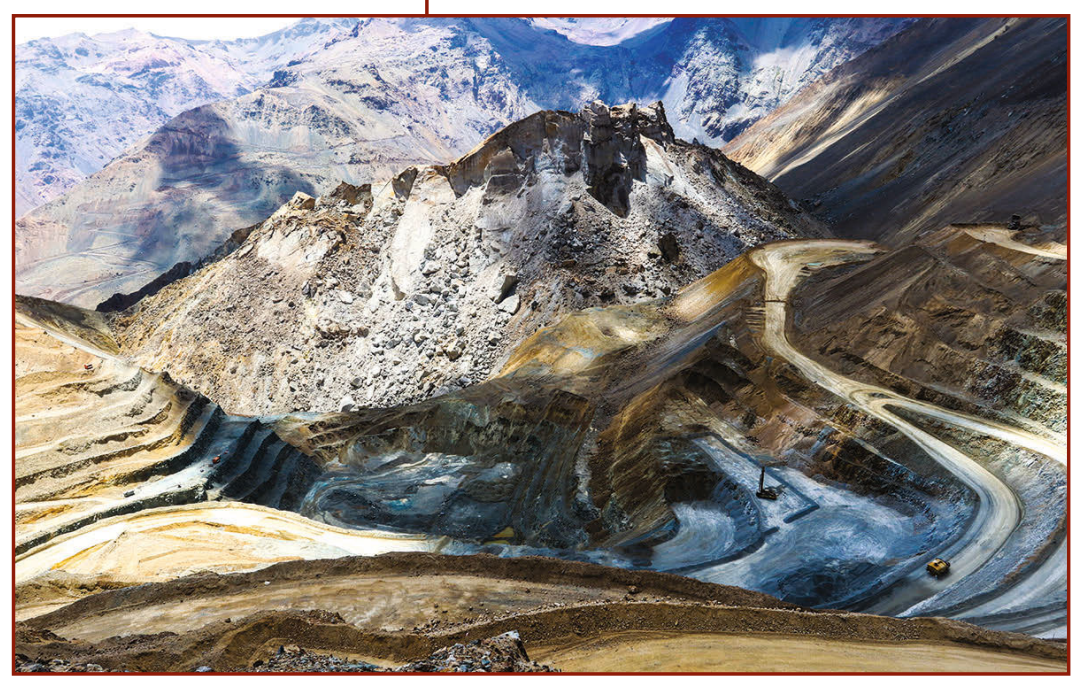

Calama, Chile: Copper producer Codelco is targeting mid-2019 to launch underground operations at its Chuquicamata mine. The site, which has been operating as an open-pit mine for more than 100 years and is one of the world's largest open-pit copper mines, produced 330,900 tonnes of copper in 2017. Codelco, the state copper producer of Chile, projects that the underground mine will produce 320,000 tonnes of fine copper and 15,000 tonnes of molybdenum after transitioning to underground operations. (Photo courtesy of Codelco.)
Elmer L. Doty, current director, to serve as president and chief operating officer.

\section{SMS Group Contracted for Compact Cold Mill}

Ravenna, Italy: Metal industry partner SMS Group has been contracted by Italian steel company Marcegaglia to supply a high-performance compact cold mill for their plant in Ravenna, Italy. The mill will be considered high-performance because it has been designed to process a comprehensive material mix, including high-carbon and duplex steels, chrome-manganese alloyed steels, and silicon steels. SMS Group and Marcegaglia aim to have the new compact cold mill fully operational by April 2020.

\section{Global Bioenergies Begins Demo Production of Isobutene Evry, France: French bioenergy} research company Global Bioenergies has successfully produced demo-scale runs of bio-isobutene from wheat straw hydrolysate. This project is part of a larger program called OPTISOCHEM, which began in June 2017 and was granted $€ 9.8$ million by the Bio Based Industry-Joint Undertaking (BBI-JU). The next phase of the project is conversion of the bioisobutene into oligomers and polymers for use in lubricants, rubbers, cosmetics, solvents, plastics, or fuel applications.

\section{Argonne Utilizes Machine Learning to Identify Materials for Solar Cells \\ Lemont, IIlinois, USA: In a partnership} with the University of Cambridge in England, the U.S. Department of Energy's (DOE) Argonne National Laboratory has developed a "design-to-device" approach that can pinpoint promising materials for use in dye-sensitized solar cells (DSSCs). Scientists have spent countless hours developing and testing thousands of different dyes for DSSCs. This project aims to increase the efficiency of such endeavors by utilizing supercomputers to identify high-performing, low-cost dye materials through an automated workflow that employs a combination of simulation, data mining, and machine learning techniques. 